\title{
Correction to: Investigation of the interaction \\ of hypoxia-inducible factor 1-alpha inhibitor, IDF-11774, with heat shock protein, HSP70, using quantum chemistry calculations
}

\author{
Najmeh Karamoozian ${ }^{1} \cdot$ Maryam Dehestani ${ }^{2} \cdot$ Reza Behjatmanesh-Ardakani ${ }^{1}$ \\ Published online: 4 July 2020 \\ (C) Springer Science+Business Media, LLC, part of Springer Nature 2020
}

\section{Correction to: Struct Chem}

https://doi.org/10.1007/s11224-020-01501-3

Corrections are needed to the original publication of this article. The author's affiliations were incorrectly assigned during submission. The authors apologize for the oversight and the correct affiliations are presented in this Erratum article.

Publisher's note Springer Nature remains neutral with regard to jurisdictional claims in published maps and institutional affiliations.

The online version of the original article can be found at https://doi.org/ 10.1007/s11224-020-01501-3

Maryam Dehestani

dehestani@uk.ac.ir

1 Department of Chemistry, Payame Noor University, Tehran, Iran

2 Department of Chemistry, Shahid Bahonar University of Kerman, Kerman, Iran 